\title{
RAPD analysis of the genetic diversity among accessions of Fabaceous forages (Poincianella spp) from the Caatinga
}

\author{
R.F.M. Mendes ${ }^{1}$, R.B. Araujo Neto ${ }^{2}$, M.P.S.B.C. Nascimento ${ }^{2}$ \\ and P.S.C. Lima ${ }^{2}$ \\ ${ }^{1}$ Universidade Federal do Piauí, Campus Universitário Ministro Petrônio Portella, \\ Teresina, PI, Brasil \\ ${ }^{2}$ Embrapa Meio-Norte, Teresina, PI, Brasil \\ Corresponding author: P.S.C. Lima \\ E-mail: paulo.costa-lima@embrapa.br
}

Genet. Mol. Res. 13 (3): 5832-5839 (2014)

Received January 7, 2014

Accepted May 28, 2014

Published August 1, 2014

DOI http://dx.doi.org/10.4238/2014.August.1.1

\begin{abstract}
Among members of the Fabaceae family, native to the Brazilian Caatinga, the species Poincianella pyramidalis and $P$. bracteosa exhibit particular potential as forage for cattle, sheep and goats. With the aim of establishing genetic relationships within Poincianella, random amplified polymorphic DNA analysis was performed on eight accessions of $P$. pyramidalis and two accessions of $P$. bracteosa, originating from the semiarid zone of the state of Piauí, northeastern Brazil, and present in the germplasm bank of Embrapa Meio Norte (Teresina, Piauí, Brazil). Amplification reactions using 11 selected arbitrary sequence primers generated 167 fragments with an overall polymorphism of $70.38 \%$. Five monomorphic loci were generated exclusively in $P$. pyramidalis accessions, while three unique monomorphic loci were associated with P. bracteosa, and these represented potential species-specific markers. The similarity coefficients between Poincianella accessions were low (mean value 0.59 ) but with a wide variation (range 0.443 to 0.748 ). The similarity
\end{abstract}


matrix and the dendrogram constructed using the unweighted pair group method allowed the separation of Poincianella accessions into two major clusters represented by the two distinct species, while the accessions of $P$. pyramidalis could be separated further into three subgroups. The high level of genetic diversity detected in the genus Poincianella could be used in future breeding programs to produce enhanced cultivars, although the variability could be better exploited if more specimens were collected from other locations within the semiarid region of northeastern Brazil.

Key words: Forage; Genetic diversity; Species-specific markers; RAPD; Plant improvement

\section{INTRODUCTION}

The availability of forage for livestock in the semiarid region of northeastern Brazil is severely limited because of sparse and irregular precipitation and high temperatures. The Caatinga vegetation, which is typical of this environment, is characterized primarily by small, thorny trees and grasses, and these constitute an important source of animal fodder. The Fabaceous trees Poincianella pyramidalis (Tul.) L.P. Queiroz (catingueira-verdadeira) and $P$. bracteosa (Tul.) L.P. Queiroz (catinga-de-porco) are native to the Caatinga and exhibit particular potential as forage crops. $P$. pyramidalis produces shoots even under conditions of low humidity and becomes green with the first rainfall of the wet season (Maia, 2004), while the leaves, flowers and pods that fall from P. bracteosa can be grazed on the ground by cattle and small ruminants such as sheep and goats (Costa et al., 2002).

A species lacking in sufficient genetic diversity may not have the capacity to respond to environmental changes, to compete with other plants or to provide an efficient defense against pests and predators. Therefore, for the purpose of plant breeding, it is essential that genetic variability be present between individuals of the same species, or between groups of interspecific crosses, or even between different species of the same genus. On this basis, knowledge regarding genetic diversity is crucial for a successful plant improvement program, particularly in the case of a non-domesticated plant such as $P$. pyramidalis.

The genetic variability within a species can be readily determined using hybridizationbased or polymerase chain reaction (PCR)-based molecular markers (Esfahani et al., 2009; Gomes et al., 2011). Random amplified polymorphic DNA (RAPD) is a powerful PCR-based tool for genetic studies that offers various advantages over other procedures by being rapid, easy to perform and relatively inexpensive. Moreover, the technique employs a single primer to detect polymorphisms in all regions of the genome with no requirement for prior knowledge of nucleotide sequences in the genomic DNA (Welsh and McClelland, 1990; Reiter et al., 1992; Williams et al., 1990, 1993; Haymer and McInnis, 1994; Ferreira and Grattapaglia, 1998). For these reasons, RAPD markers have been used in phylogenetic analysis, fingerprinting and genome mapping (Smith, 1995; Smith and Register, 1998). RAPD markers have been used to assess genetic diversity in the Fabaceous forage species Flemingia macrophylla (Anderson et al., 2006), Desmodium sp. (Irshad et al., 2009), Lablab purpureus (Rai et al., 2010), and Stylosanthes capitata and S. macrocephala (Chiari et al., 2010). Information regarding the genetic diversity of Poincianella species is, however, somewhat scarce. The aim of the present 
study was, therefore, to analyze accessions of $P$. pyramidalis and $P$. bracteosa available in the germplasm collection of Embrapa Meio-Norte using RAPD markers.

\section{MATERIAL AND METHODS}

\section{Plant material and extraction of DNA}

Eight accessions of $P$. pyramidalis (PP2-PP6, PP8-PP10) and two accessions of $P$. bracteosa (FG1 and FG2) were present in the germplasm collection of Embrapa Meio-Norte (Teresina, PI, Brazil), all of which originated from the municipality of São João do Piauí located $450 \mathrm{~km}$ south of Teresina within the Serra da Capivara National Park. Young healthy leaves were collected from the accessions and stored in the freezer at $-20^{\circ} \mathrm{C}$ until required for analysis. Leaf samples (100 mg) were macerated separately in a Precellys ${ }^{\circledR} 24$ tissue homogenizer/grinder (Bertin, Montigny-le-Bretonneux, France) together with extraction buffer from a DNeasy Plant kit (Qiagen, São Paulo, SP, Brazil) following the procedure recommended by the manufacturer. Aliquots of extracted DNA were subjected to electrophoresis on a $0.8 \%$ agarose gel in Tris-borate-EDTA (0.5X TBE) buffer and subsequently stained with GelRed ${ }^{\mathrm{TM}}(10,000 \mathrm{X}$; Biotium, Hayward, CA, USA). Genomic DNA was quantified by comparison with $100 \mathrm{ng} \lambda$ DNA standards, and DNA samples were stored at $-20^{\circ} \mathrm{C}$ until required for RAPD analysis.

\section{RAPD analysis}

Samples of genomic DNA were amplified using 100 arbitrary sequence decamer primers obtained from Operon Technologies (Alameda, CA, USA), and the most suitable primers were selected for RAPD reactions. Eleven primers (Table 1) were chosen on the basis of resolution and high levels of polymorphism, and these were subsequently employed in the PCR amplification of DNA samples derived from the ten accessions of Poincianella. Amplification reactions were carried out in $0.2 \mathrm{~mL}$ microtubes using a Veriti 96 Well Thermal Cycler (Applied Biosystems, Foster City, CA, USA) with a reaction mixture comprising $20 \mu \mathrm{L} 1 \mathrm{X}$ Invitrogen buffer (Life Technologies do Brasil, São Paulo, SP, Brazil), $3.0 \mathrm{mM} \mathrm{MgCl}, 0.25 \mathrm{mM}$ dNTP, 1 U Taq DNA polymerase (Invitrogen), $0.2 \mu \mathrm{M}$ primer, $1 \mu \mathrm{L}$ DNA template ( $\sim 15 \mathrm{ng})$, and ultrapure distilled water to a final volume of $20 \mu \mathrm{L}$. The PCR conditions were: initial denaturation for $1 \mathrm{~min}$ at $92^{\circ} \mathrm{C}$, 45 cycles comprising denaturation for $1 \mathrm{~min}$ at $92^{\circ} \mathrm{C}$, annealing for $1 \mathrm{~min}$ at $35^{\circ} \mathrm{C}$ and extension for $2 \mathrm{~min}$ at $72^{\circ} \mathrm{C}$, and final extension for $5 \mathrm{~min}$ at $72^{\circ} \mathrm{C}$. The resulting amplicons were separated by electrophoresis on $1.5 \%$ agarose gel in $0.5 \mathrm{X}$ TBE buffer at $110 \mathrm{~V}$ for approximately $3 \mathrm{~h}$, stained with GelRed ${ }^{\mathrm{TM}}$, visualized under a UV transilluminator and subsequently photographed.

\section{Phylogenetic analysis}

The number of well-resolved and intense polymorphic bands generated by each primer was determined by visual inspection. Each band was considered to represent a single character, and a binary matrix was created in which 1 indicated the presence of the marker and 0 its absence. Genetic similarities between accessions of Poincianella species were estimated from Dice coefficients and the corresponding similarity matrix. A dendrogram was constructed using the unweighted pair group method with arithmetic average (UPGMA) clustering technique. The cophenetic correlation coefficient $(r)$ was calculated from the similarity matrix and the 
dendrogram. The bootstrap confidence index was also evaluated from the binary matrix of amplified fragments generating a dendrogram from 1000 permutations. The cut-off point was based on the mean genetic similarity $\left(s g_{\mathrm{m}}\right)$ calculated according to the equation $s g_{\mathrm{m}}=\Sigma s g_{\mathrm{ij}} / \mathrm{N}$, in which $s g_{i j}$ is the genetic similarity between pairs of individuals and $N$ is the number of pairs obtained from 1000 permutations. Analyses were performed with the aid of the PAST version 1.34 software (Hammer et al., 2001).

Table 1. Numbers of amplified and polymorphic loci obtained following amplification of genomic DNA from 10 accessions of Poincianella pyramidalis and P. bracteosa using primers selected.

\begin{tabular}{|c|c|c|c|}
\hline Primer & Nucleotide sequence & No. of amplified loci & No. of polymorphic loci \\
\hline A08 & 5' GTG ACG TAG G 3' & 22 & 22 \\
\hline A09 & 5' GGG TAA CGC C $3^{\prime}$ & 11 & 11 \\
\hline F02 & $5^{\prime}$ GAG GAT CCC T 3' & 17 & 16 \\
\hline M01 & 5' GTT GGT GGC T 3' & 16 & 14 \\
\hline M04 & 5' GGC GGT TGT C 3' & 10 & 9 \\
\hline M15 & 5' GAC CTA CCA C $3^{\prime}$ & 17 & 16 \\
\hline M19 & 5' CCT TCA GGC A 3' & 14 & 14 \\
\hline M20 & 5' AGG TCT TGG G 3' & 11 & 11 \\
\hline N06 & 5' GAG ACG CAC A 3' & 16 & 16 \\
\hline N08 & 5' ACC TCA GCT C 3' & 14 & 11 \\
\hline P06 & 5' GTG GGC TGA C 3' & 19 & 15 \\
\hline
\end{tabular}

\section{RESULTS AND DISCUSSION}

The 11 primers selected for RAPD analysis of the accessions of Poincianella species generated a total of 167 loci, with an average of 15.18 (range 10 to 22) loci per primer (Table 1). In comparison, RAPD analysis of the leguminous forage Stylosanthes guianensis performed by Chiari et al. (2006) generated an average of only 5.25 loci per primer. The loci generated by primers A08, N06, M19, A09, and M20 were exclusively polymorphic (with 22, $16,14,11$, and 11 bands, respectively), while the loci generated by primer N08 showed the least polymorphism (78.57\%). Figure 1 shows an example of the electrophoretic profile of RAPD amplifications of DNA samples from $P$. pyramidalis and $P$. bracteosa generated by primer A08. The sizes of the amplified fragments ranged between 396 and $4000 \mathrm{bp}$, a variation that is much greater than that established by Santos et al. (2012) for 13 accessions of $P$. pyramidalis (250-1000 bp) or those reported by Andersson et al. $(2006,2007)$ for F. macrophylla (440-2500 bp) and Cratylia argentea (320-2900 bp).

Monomorphic bands that were unique to $P$. pyramidalis accessions were generated by primers P06 (1550 bp), M20 (1400 and 1500 bp), M01 (2000 bp), and F02 (2200 bp), while primers A09 (500 bp), M15 (1600 bp) and N08 (3054 bp) produced monomorphic bands that were exclusive to $P$. bracteosa. Such unique bands not only distinguish the two species of Poincianella but also represent potential species-specific markers.

Of the 144 fragments produced by accessions of $P$. pyramidalis in the germplasm collection of Embrapa Meio Norte, 126 were polymorphic, indicating a polymorphism of $87.50 \%$. This value is lower than the $94.6 \%$ polymorphism reported by Santos et al. (2012) for accessions of $P$. pyramidalis collected in the State of Sergipe, but greater than those reported for six species of Acacia, an economically important genus within the Fabaceae (Nanda et al., 2004). The level of polymorphism observed in the two accessions of P. bracteosa was $53.26 \%$ (49/92), a value that is higher than that found in accessions of $S$. capitata $(39.13 \%)$ and $S$. mac- 
rocephala (34.28\%) as reported by Chiari et al. (2010).

The high level of polymorphism detected in accessions of Poincianella species is probably due to the self-incompatibility of plants of this genus. According to Leite and Machado (2009), P. pyramidalis forms fruits only when there is manual or natural crosspollination. Additionally, these non-domesticated species still preserve their original genetic traits, since they have not been submitted to artificial selection. As stated by Clement (2001), the lower the degree of domestication of a species, the greater the level of genetic variability is detected.

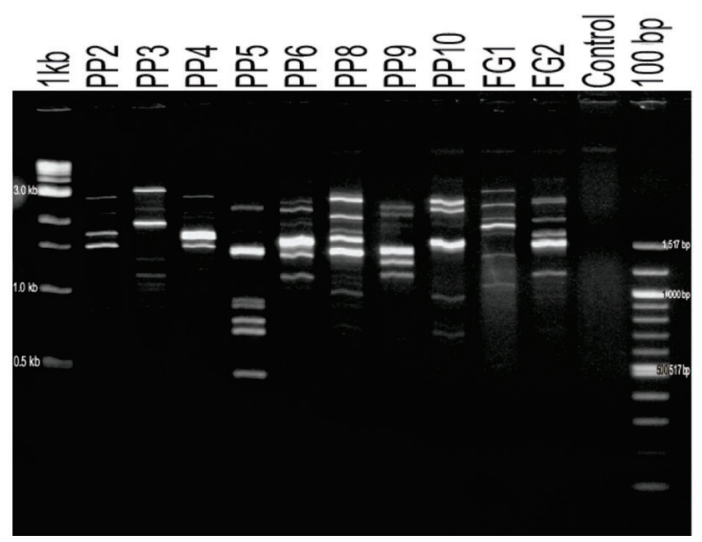

Figure 1. Electrophoretic profiles of RAPD amplifications of DNA samples from eight accessions of Poincianella pyramidalis (PP2-PP6, PP8-PP10) and two accessions of P. bracteosa (FG1 and FG2) generated by primer A08.

The genetic similarity matrix presented in Table 2 reveals that the coefficients between Poincianella accessions were low but varied widely. The mean similarity coefficient was 0.59 (range 0.443 to 0.748 ), a value that is higher than that reported by Croft et al. (1999) for species of Lathyrus. On the other hand, the mean similarity coefficient and the range of variation obtained in the present study were smaller than those reported by Santos et al. (2012), although these authors employed a larger number of Poincianella accessions in their RAPD analysis. It would appear, therefore, that accessions originating from the semiarid region of Piaui studied herein exhibit less similarity than those from Sergipe investigated by Santos et al. (2012).

The similarity coefficients within the accessions of $P$. pyramidalis ranged from 0.504 to 0.748 , with accessions PP4 and PP8 being the most similar and PP2 and PP6 the most divergent. The two P. bracteosa accessions FG1 and FG2 showed moderate similarity (0.637), while the lowest similarity (0.443) was observed between accessions PP2 and FG2 of the different species. In contrast, Chiari et al. (2010) employed 26 primers in a RAPD analysis of two species of Stylosanthes and obtained high coefficients of similarity with small ranges of variation. For example, the coefficients in $S$. capitata varied from 0.741 to 0.913 , while in $S$. macrocephala the range was between 0.724 and 0.924 . Hence, the intraspecific variation in Stylosanthes was much less pronounced than that observed for Poincianella in the present study.

The cophenetic correlation $(r=0.87)$ confirmed good agreement between the Dice similarity matrix and the dendrogram constructed using the UPGMA method, thereby increasing the reliability of the interpretations related to genetic distances. Delimitation of the den- 
drogram with a cut-off point of 0.59 revealed the genetic interrelationships between the ten Poincianella accessions and allowed the separation of the accessions into two major clusters (Figure 2) represented by the two distinct species, P. bracteosa (group I) and P. pyramidalis (group II). Additionally, the accessions of $P$. pyramidalis could be separated intro three subgroups, namely IIA (PP5 and PP10), IIB (PP4,PP8,PP9, and PP6), and IIC (PP3 and PP2).

\begin{tabular}{|c|c|c|c|c|c|c|c|c|c|}
\hline Accession & PP2 & PP3 & PP4 & PP5 & PP6 & PP8 & PP9 & PP10 & FG1 \\
\hline PP3 & 0.72000 & & & & & & & & \\
\hline PP4 & 0.61905 & 0.63415 & & & & & & & \\
\hline PP5 & 0.59420 & 0.68148 & 0.58824 & & & & & & \\
\hline PP6 & 0.50370 & 0.63636 & 0.64662 & 0.59310 & & & & & \\
\hline PP8 & 0.61654 & 0.66154 & 0.74809 & 0.55944 & 0.67143 & & & & \\
\hline PP9 & 0.60870 & 0.69630 & 0.69118 & 0.67568 & 0.67586 & 0.72727 & & & \\
\hline PP10 & 0.57576 & 0.63566 & 0.58462 & 0.66197 & 0.51799 & 0.59854 & 0.64789 & & \\
\hline FG1 & 0.55285 & 0.56667 & 0.51240 & 0.49624 & 0.55385 & 0.50000 & 0.54135 & 0.47244 & \\
\hline FG2 & 0.44286 & 0.54015 & 0.47826 & 0.49333 & 0.54422 & 0.49655 & 0.49333 & 0.44444 & 0.63704 \\
\hline
\end{tabular}

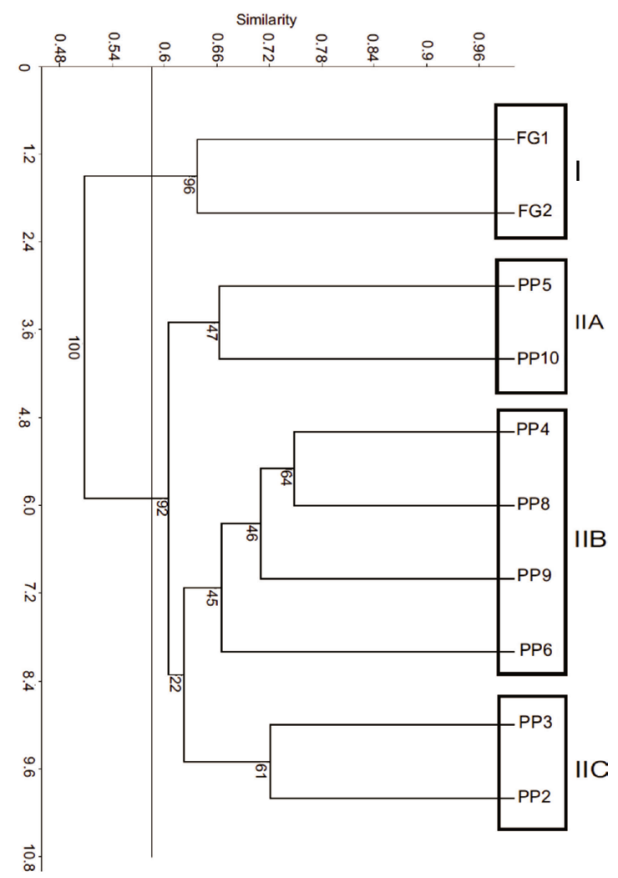

Figure 2. UPGMA dendrogram based on 11 RAPD polymorphic markers showing similarity relationships between eight accessions of Poincianella pyramidalis (PP2-PP6, PP8-PP10) and two accessions of P. bracteosa (FG1 and FG2).

It is important to emphasize that all accessions studied originated from the municipality of São João do Piauí. The distribution of the accessions into four clusters demonstrated the large genetic diversity present in the genus Poincianella and indicated that this variability 
could be better exploited if more specimens were collected from other locations in the semiarid region of northeastern Brazil.

The RAPD marker technique was shown to be an appropriate tool for establishing genetic relationships within the genus Poincianella, since it was possible to observe a high degree of polymorphism, especially in P. pyramidalis ( $87.50 \%)$. A large genetic diversity among the ten Poincianella accessions available in the germplasm collection of Embrapa Meio-Norte was detected, and this resource could be employed in future breeding programs to generate enhanced cultivars. The non-domesticated nature Poincianella spp was considered to be the main factor responsible for the extensive genetic variability observed among the accessions.

\section{ACKNOWLEDGMENTS}

\section{Research supported by Embrapa-Macroprograma 1.}

\section{REFERENCES}

Andersson MS, Peters M, Schultze-Kraft R, Gallego G, et al. (2006). Molecular characterization of a collection of the tropical multipurpose shrub legume Flemingia macrophylla. Agroforest. Syst. 68: 231-245.

Andersson MS, Schultze-Kraft R, Peters M, Duque MC, et al. (2007). Extent and structure of genetic diversity in a collection of the tropical multipurpose shrub legume Cratylia argentea (Desv.) O. Kuntze as revealed by RAPD markers. Electron. J. Biotechnol. 10: 386-399.

Chiari L, Valle JVR, Resende RMS and Cançado LJ (2006). Análise da Diversidade Genética em Stylosanthes guianensis Utilizando Marcadores RAPD. Boletim de Pesquisa e Desenvolvimento 20. Embrapa Gado de Corte, Campo Grande.

Chiari L, Jerba VF, Fernandes CD and Resende RMS (2010). Variabilidade Genética Molecular Entre Acessos de Stylosanthes capitata e Stylosanthes macrocephala, Resistentes e Suscetíveis à Antracnose. Boletim de Pesquisa e Desenvolvimento 27. Embrapa Gado de Corte, Campo Grande.

Clement CR (2001). Melhoramento de Espécies Nativas. In: Recursos Genéticos \& Melhoramento - Plantas (Nass LL, Valois ACC, Melo IS and Valadares-Inglis MC, eds.). Fundação de Apoio à Pesquisa Agropecuária de Mato Grosso, Rondonópolis, 423-441.

Costa JAS, Nunes TS, Ferreira APL and Stradmann MTS (2002). Leguminosas Forrageiras da Caatinga: Espécies Importantes para as Comunidades Rurais do Sertão da Bahia. Universidade Estatual de Feira de Santana, Feira de Santana.

Croft AM, Pang ECK and Taylor PWJ (1999). Molecular analysis of Lathyrus sativus L. (grasspea) and related Lathyrus species. Euphytica 107: 167-176.

Esfahani ST, Shiran B and Balali G (2009). AFLP markers for the assessment of genetic diversity in European and North American potato varieties cultivated in Iran. Crop Breed. Appl. Biotechnol. 9: 75-86.

Ferreira ME and Grattapaglia D (1998). Introdução ao Uso de Marcadores Moleculares em Análise Genética. 3rd edn. Embrapa/Cenargen, Brasília.

Gomes LRP, Lopes MTG, Bento JLS, Barros WS, et al. (2011). Genetic diversity in natural populations of buriti (Mauritia flexuosa L. f.). Crop Breed. Appl. Biotechnol. 11: 216-223.

Hammer O, Harper DAT and Ryan PD (2001). PAST: Paleontological statistics software package for education and data analysis. Paleontol. Electron. 4: 1-9.

Haymer DS and McInnis DO (1994). Resolution of populations of the Mediterranean fruit fly at the DNA level using random primers for the polymerase chain reaction. Genome 37: 244-248.

Irshad S, Singh J, Kakkar P and Mehrotra S (2009). Molecular characterization of Desmodium species - an important ingredient of 'Dashmoola' by RAPD analysis. Fitoterapia 80: 115-118.

Leite AV and Machado IC (2009). Biologia reprodutiva da "catingueira" (Caesalpinia pyramidalis Tul., LeguminosaeCaesalpinioideae), uma espécie endêmica da Caatinga. Rev. Bras. Bot. 32: 79-88.

Maia GN (2004). Catingueira. In: Caatinga: Árvores e Arbustos e suas Utilidades (Maia GN, ed.). Leitura e Arte, São Paulo, 159-169.

Nanda RM, Nayak S and Rout GR (2004). Studies on genetic relatedness of Acacia tree species using RAPD markers. 
Biologia 59: 115-120.

Rai N, Kumar A, Singh PK and Singh M (2010). Genetic relationship among hyacinth bean (Lablab purpureus) genotypes cultivars from different races based on quantitative traits and random amplified polymorphic DNA marker. Afr. $J$. Biotechnol. 9: 137-144.

Reiter RS, Williams JG, Feldmann KA, Rafalski JA, et al. (1992). Global and local genome mapping in Arabidopsis thaliana by using recombinant inbred lines and random amplified polymorphic DNAs. Proc Natl. Acad. Sci. U. S. A. 89: 1477-1481.

Santos JS, Mendes SS, Conde DC and Delmondez RC (2012). Genetic diversity assessment of Poincianella pyramidalis (Tul.) L.P. Queiroz accessions using RAPD markers. Sci. Plena 8: 1-8.

Smith JSC (1995). Identification of Cultivated Varieties by Nucleotide Analysis. In: Identification of Food-Grain Varieties (Wrigley CW, ed.). American Association of Cereal Chemists, St. Paul, 131-150.

Smith JSC and Register JC (1998). Genetic purity and testing technologies for seed quality: a company perspective. Seed Sci. Res. 8: 285-293.

Welsh J and McClelland M (1990). Fingerprinting genomes using PCR with arbitrary primers. Nucleic Acids Res. 18: 7213-7218.

Williams JG, Kubelik AR, Livak KJ, Rafalski JA, et al. (1990). DNA polymorphisms amplified by arbitrary primers are useful as genetic markers. Nucleic Acids Res. 18: 6531-6535.

Williams JG, Hanafey MK, Rafalski JA and Tingey SV (1993). Genetic analysis using random amplified polymorphic DNA markers. Methods Enzymol. 218: 704-740. 